\title{
EVALUATION OF POSSIBILITY OF OBTAINING WOODCHIPS FROM WOOD RESIDUES
}

\author{
Aleksandr Mokhirev*, Mihail Zyryanov, Tatyana Ryabova, Aleksandr Vititnev \\ Lesosibirsk Branch of Reshetnev Siberian State University of Science and Technology Lesosibirsk
}

For the moment, the priority for the development of forestry is the provision of continuous, non-exhaustive and rational use of forest resources. In spite of this, logging residues, i.e. brushwood, twigs, tree tops, butt end and cull wood, which are unavoidably formed due to logging processes, are ploughed and burned. Analysis of this type of logging debris showed that logging residues are up to $18 \%$ of the total wood biomass and they are potential raw materials for obtaining woodchips for fuel and other types of products. The study presents evidence-based and experimentally confirmed possibility of obtaining woodchips for fiber board, pulp and paper industry. The influence of the wood species and the type of logging residues on the quality indicators of chip was established.

Key words: Chip, Brushwood, Twigs, Tree tops, Raw materials, Wood processing, Logging residues, Logging technologies, Integrated use of wood, Logging debris

\section{INTRODUCTION}

At present, when the need for wood is constantly increasing, its integrated use is acquiring particular importance. In the coming years, the national economy's need for wood will be satisfied at the expense of its economical and most complete use by increasing volumes of logging [1].

In this regard, the main forestry complex development direction is improving the use of all the wood pulp produced. Therefore, it is necessary to further improve the structure of forestry and wood processing industry production, to develop production of woodchips, wood boards, plywood, containerboards, and other alternative industrial wood.

Improving the use of wood biomass, implementing low quality, low-value wood, logging residues, logging debris and wood processing is a quite urgent task.

However, the issue of logging debris processing is still not completely resolved. In reality, they are ploughed, burned or just left to rot through. After all, utilized wood is precious natural raw material that can compensate the needs for production of a number of commercial outputs $[2,3]$.

One of priorities of using of logging debris in the form of brushwood, twigs, tree tops is to our mind, their chipping. This is confirmed by many studies [4-6].

In its turn, a woodchip is widely used in various industries. With its humidity content not less than $40 \%$ it can be used as raw wood material in pulp and paper industry and wood processing industry for the production of containerboard, industrial paper grades, wood fiber boards and chipboards. When chipping by chemical energetic means, acids, alcohols, aldehydes, ethers, resin, coal, gas are obtained. Woodchip is also applied in hydrolysis production [7].

The studies [8-10] showed that both chips from the birch wood and disintegrated alder and hazel scrub can be used as organic filler in production of wood-cement for industrial premises that are under construction.

Small-diameter chip is used as feed supplement, as bedding for animals and poultry and for making composts. Fuel chip is intended for burning in boiler plants, residential heaters and production furnaces. The energy chip in the form of bricks, without adding any binders, is used for the same purpose. Production of fuel brick from disintegrated wood is highly effective in mobile units [9-11].

As a result, the purpose of this study was to give scientific credence and confirm experimentally the possibility of obtaining woodchips from logging residues.

\section{EXPERIMENTAL PART}

To analyze the volume of formation of logging residues and their type there was performed a preliminary experiment at 9 logging areas of Krasnoyarsky region, the Russian Federation. On these logging areas, logging residues were collected from each cut down tree. The number of trees - 140, diameter - from 16 up to $68 \mathrm{~cm}$, all of various species. Logging residues were divided into twigs, large brushwood, small brushwood, tops [12]. Each logging residue species was processed into chip by using a wood chipper. A chip was assessed by its fractional composition and compared to a chip of various purpose required for production.

\section{RESULTS AND DISCUSSION OF EXPERIMENT}

The results of preliminary experiment showed that tree diameter has the most significant impact on logging residues amount. The characteristic curve in the table 1 shows, that with increase of a tree first log diameter up to 30-34 cm, the content of logging debris sharply reduces from 12 to $9.5 \%$. With further increase of the tree first log diameter, the logging residue percentage reduces less intensively and reaches $7 \%$ for the diameter of $66-68 \mathrm{~cm}$. 


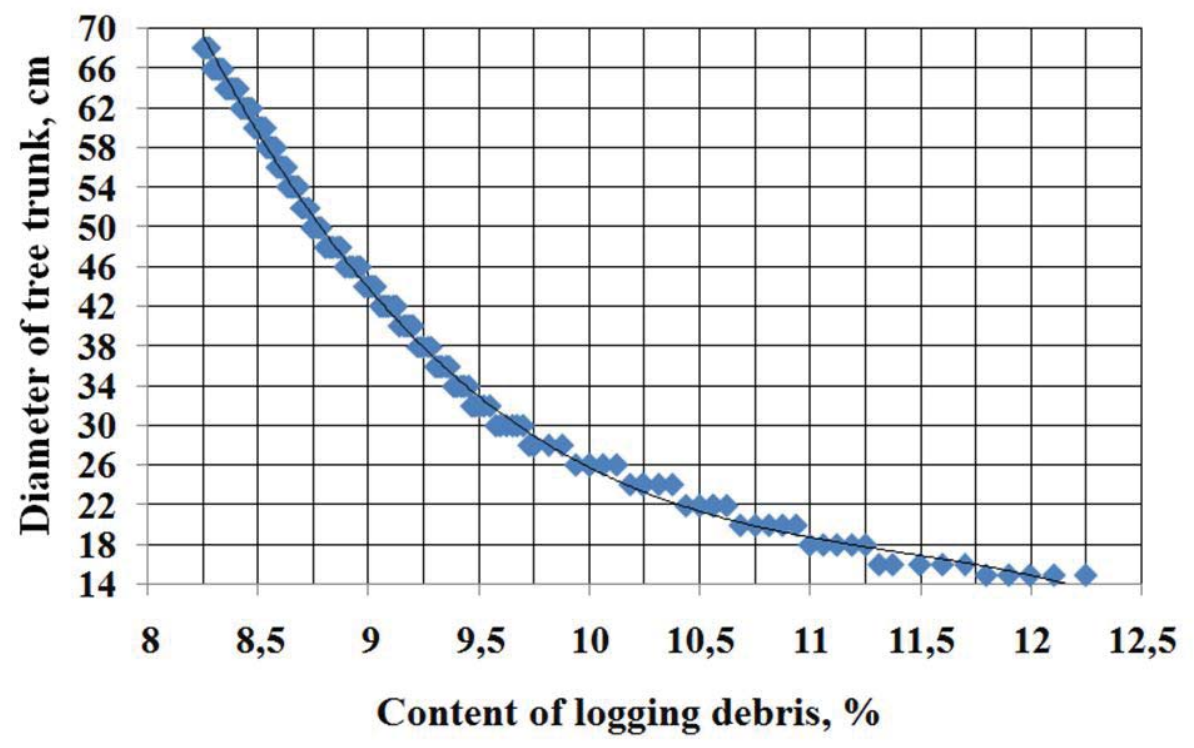

Figure 1: Relationship between a volume of logging debris and a diameter of tree trunk

According to the characteristic curve introduced in the figure 2, the volume of brushwood fluctuates within
$3-4.5 \%$ of a whole tree volume, twigs $-4.5-6.5 \%$, and tree tops $-0.5-1 \%$.

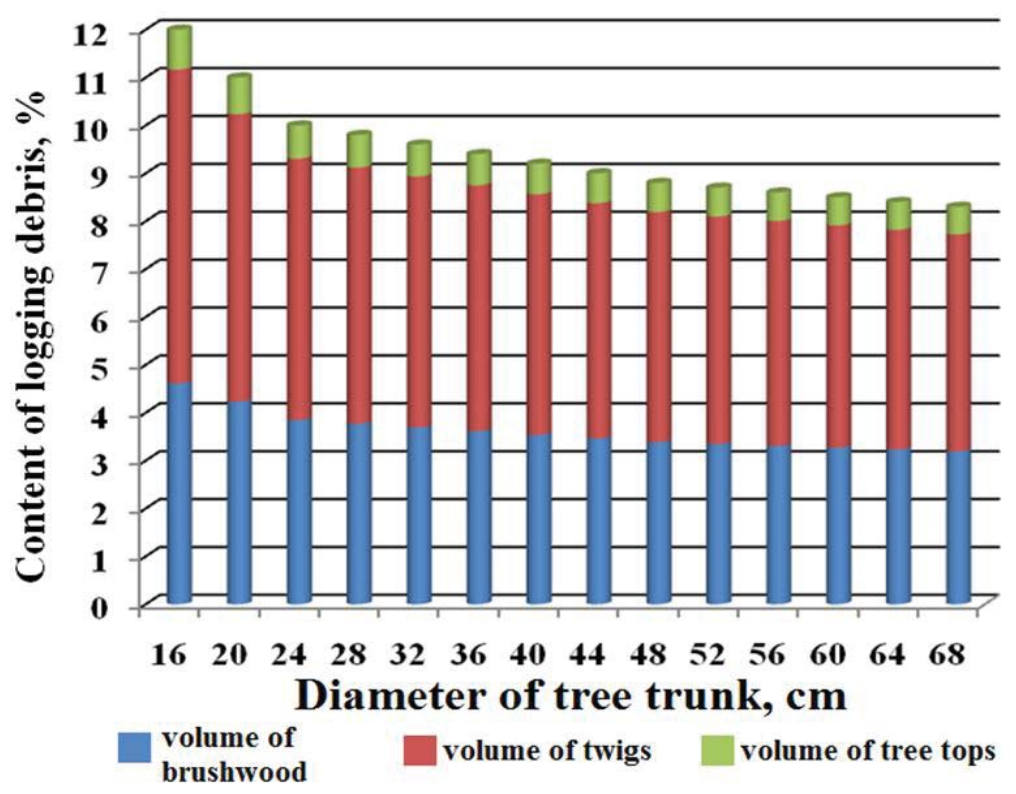

Figure 2: Relationship between the content of various logging debris types and a tree trunk diameter

The table 1 shows characteristics of accept chips that were taken for evaluation of quality indicators of wood raw materials from logging residues.
According to the experimental results introduced in the table 2, the woodchips can be obtained from: largeseized brushwood of pine, spruce, birch; tops and smallseized brushwood of pine. Logging debris of other species can be used for production of small-diameter and fuel chips. 
Table 1: Chip characteristics

\begin{tabular}{|c|c|c|c||c|c|c|}
\hline $\begin{array}{c}\text { Type of } \\
\text { chip }\end{array}$ & $\begin{array}{c}\text { Chip } \\
\text { length } \\
\text { mm }\end{array}$ & $\begin{array}{c}\text { Chip } \\
\text { width } \\
\text { mm }\end{array}$ & $\begin{array}{c}\text { Angle } \\
\text { of cut } \\
\text { degrees }\end{array}$ & $\begin{array}{c}\text { Bark mass } \\
\text { fraction } \\
\%\end{array}$ & $\begin{array}{c}\text { Decay mass } \\
\text { fraction } \\
\%\end{array}$ & Purpose \\
\hline \multirow{2}{*}{ Woodchip } & $12-15$ & to 5 & $30-60$ & $\begin{array}{c}1 \\
1.5 \\
3\end{array}$ & $\begin{array}{c}- \\
0.3\end{array}$ & $\begin{array}{c}\text { Pulp and } \\
\text { paper } \\
\text { industry }\end{array}$ \\
\cline { 2 - 7 } & $10-35$ & to 5 & $30-60$ & 15 & 5 & $\begin{array}{c}\text { Production } \\
\text { of wood } \\
\text { fiber boards }\end{array}$ \\
\cline { 2 - 7 } & $10-60$ & to 30 & $30-60$ & 15 & 5 & $\begin{array}{c}\text { Chipboard } \\
\text { production }\end{array}$ \\
\hline \multirow{2}{*}{ Fuel } & $5-50$ & to 10 & - & 20 & 5 & $\begin{array}{c}\text { Burning } \\
\text { Small }\end{array}$ \\
\hline \multirow{2}{*}{ diameter } & $15-30$ & to 5 & - & - & 5 & $\begin{array}{c}\text { Feed } \\
\text { supplement, } \\
\text { compost, } \\
\text { bedding }\end{array}$ \\
\hline
\end{tabular}

Table 2: Results of experiments

\begin{tabular}{|c|c|c|c|}
\hline Species & Debris type & Diameter, cm & Chip type \\
\hline \multirow{4}{*}{ Pine } & Tree tops & $5-16$ & Woodchip \\
\hline & Small-sized brushwood & $4-10$ & Technological \\
\hline & Large-sized brushwood & more than 10 & Technological \\
\hline & Twigs & up to 4 & Small-diameter \\
\hline \multirow{4}{*}{ Spruce } & Tree tops & $5-16$ & Small-diameter \\
\hline & Small-sized brushwood & $4-10$ & Small-diameter \\
\hline & Large-sized brushwood & more than 10 & Technological \\
\hline & Twigs & up to 4 & Small-diameter \\
\hline \multirow{4}{*}{ Fir } & Tree tops & $5-16$ & Small-diameter \\
\hline & Small-sized brushwood & $4-10$ & Small-diameter \\
\hline & Large-sized brushwood & more than 10 & Fuel \\
\hline & Twigs & up to 4 & Small-diameter \\
\hline \multirow{4}{*}{ Birch } & Tree tops & $5-16$ & Fuel \\
\hline & Small-sized brushwood & $4-10$ & Small-diameter \\
\hline & Large-sized brushwood & more than 10 & Technological \\
\hline & Twigs & up to 4 & Small-diameter \\
\hline
\end{tabular}




\section{CONCLUSION}

Therefore, the results of study showed that $8-11 \%$ of logging debris of pine and 3-4\% of birch and spruce are suitable for obtaining woodchip. This is primarily due to the fact that the chips with the required geometric dimensions are obtained from large felling residues that predominate in pine. From small and medium-sized felling residues, due to the design features of the chippers, fine chips of rectangular shape are obtained. This chip does not meet the requirements for technological chips.

\section{ACKNOWLEDGEMENT}

The reported study was funded by Russian Foundation for Basic Research, Government of Krasnoyarsk Territory, Krasnoyarsk Regional Fund of Science, to the research project: "Research and modelling of economic development of the forest industry in the region in the context of climatic conditions and resource potential", Grant № 18-410-240003

\section{REFERENCES}

1. Zyryanov, M.A. (2010). Processing of wood wastes in production of wood fiber board, Bulletin of KSAU, No. 4. pp. 288-291.

2. Bezrukikh, Y.A., Medvedev, S.O., Alashkevich, Y.D., \& Mokhirev, A.P. (2014). Rational natural resources management in the conditions of development industrial enterprises of forestry complex, Economics and Enterprise, No. 12-2.-pp. 994-996.

3. Kärhä, K. (2007). Production and Use of Wood Chips: Improving Supply Chains. In Wood Energy UNECE/FAO Workshop, Belgrade: Serbia. P. 68.

4. Heikkilä, J., Tanttu, J.V., Lindblad, J., Sirén, M., \& Asikainen, A. (2006). Harvesting alternatives and cost factors of delimbed energy wood: Metsanduslikud Laitila, Uurimused -Forestry Studies. No 45. pp. 49-56.

5. Gerasimov, Y., \& Karjalainen, T. (2011), Energy wood resources in Northwest Russia, Biomass and Bioenergy, 35(5), 1655-1662. doi:10.1016/j.biombioe.2010.12.039
6. Goltsev, V., llavský, J., Gerasimov, Y., \& Karjalainen, T. (2010). Potential for biofuel development in Tihvin and Boksitogorsk districts of the Leningrad region - The analysis of energy wood supply systems and costs. Forest Policy and Economics, 12(4), 308-316. doi:10.1016/j.forpol.2009.10.007

7. Vasiliev, S.B., Patyakin, V.I., \& Shegelman, I.R. (2001). Engineering and technologies of chipping production at logging companies, Petrozavodsk: Publ. PSU.

8. Mokhirev, A.P., Bezrukikh, A.(., \& Medvedev, S.O. (2015). Processing of wood wastes of forestry complex enterprises as a factor of sustainable use of natural resources, Engineering bulletin of Don, Engineering bulletin of Don. No. 2, p 2, URL: http://www. ivdon.ru/ru/magazine/archive/n2p2y2015/3011

9. Mokhirev, A.P., Aksenov, N.V., \& Sheverev, O.V. (2014). On rational management of natural resources and exploitation of resources in Krasnoyarsky krai, Engineering bulletin of Don, No. 4-1 URL: ivdon. ru/ru/magazine/archive/N4y2014/2569.

10. Shchukin, P.O., Demchuk, A.V., \& Budnik, P.V. (2012). Improvement of the efficiency of processing of logging secondary resources into fuel chip, Engineering bulletin of Don, No.3. URL: http://ivdon.ru/ magazine/archive/n3y2012/1025.

11. Shegelman, I.R. (2014). Development of technological logging process using feller-skidder on the basis of functional and technical, Engineering bulletin of Don, No.3. URL: http://www.ivdon.ru/ru/magazine/ archive/n3y2014/2457.

12. Mokhirev, A.P., \& Zyryanov, M.A. (2015). Technologies of logging operations with sorting of logging residues, Systems, Methods. Technologies, No. 3. pp. 118-122. 